\title{
POLITIKK
}

\section{Hva nå, norsk forsvarsindustri? Instrumentelle og institusjonelle svar på EUs nye politikk på det sikkerhets- og forsvarspolitiske området}

\author{
Kari Tvetbråten \\ Forsvarets forskningsinstitutt (FFI) \\ Bjørn Olav Knutsen \\ Forsvarets forskningsinstitutt (FFI) og Nord universitet
}

\begin{abstract}
Sammendrag
Artikkelen diskuterer EUs nye forsvarspakke med særlig vekt på CARD (Coordinated Annual Review on Defence), PESCO (Permanent Structured Cooperation) og EDF (European Defence Fund). Formålet er å styrke EU som sikkerhetspolitisk aktør og legge grunnlaget for europeisk strategisk autonomi. Forsvarspakken utfordrer norsk sikkerhets-, forsvars- og forsvarsindustripolitikk. Problemstillingene artikkelen besvarer, er: Hva innebærer EUs nye forsvarspakke? Hvordan og hvorfor har norske myndigheter og forsvarsindustri så langt håndtert de endringer som kommer som følge av denne? Vi legger instrumentelle og institusjonelle teorier og perspektiver til grunn for analysen. Instrumentelle teorier forteller at aktørene handler formålsrasjonelt etter en konsekvenslogikk. Institusjonelle teorier forteller at aktørene søker legitimitet og handler i tråd med etablert kultur og forventninger i omgivelsene. EU får en økende betydning der unionens sikkerhets- og forsvarspolitikk blir likere EUs andre politikkområder. Våre intervjuer med representanter for norske myndigheter og forsvarsindustri forteller at de har fragmentert kunnskap om og forventninger til betydningen av EUs forsvarspakke. Vi konkluderer at aktørene har en instrumentell tilnærming, men at manglende helhetlig forståelse gjør det vanskelig å svare formålsrasjonelt. Aktørene handler derfor også i tråd med et kulturperspektiv.
\end{abstract}

Nøkkelord: EU • organisasjonsteori • forsvarsforskningspolitikk • forsvarsindustripolitikk

\footnotetext{
^Kontaktinformasjon: Kari Tvetbråten, e-post: karitvet@yahoo.no

(C2019 Kari Tvetbråten og Bjørn Olav Knutsen. This is an Open Access article distributed under the terms of the Creative Commons Attribution 4.0 International License (http://creativecommons.org/licenses/by/4.0/), allowing third parties to copy and redistribute the material in any medium or format and to remix, transform, and build upon the material for any purpose, even commercially, provided the original work is properly cited and states its license. Citation: Kari Tvetbråten og Bjørn Olav Knutsen (2019). Hva nå, norsk forsvarsindustri? Instrumentelle og institusjonelle svar på EUs nye politikk på det sikkerhets- og forsvarspolitiske området. Internasjonal Politikk, 77(4): 398-419. http://dx. doi. org/10.23865/intpol.v77.1611
} 


\section{Innledning}

En nasjonal forsvarsindustri er viktig for Norges sikkerhet. I Meld. St. nr. 9 (20152016) redegjør regjeringen for Norges forsvarsindustrielle strategi. Meldingen understreker at norsk forsvarsindustri må inneha kompetanse på områder som er vesentlige for å ivareta Norges sikkerhet. Myndighetene vil derfor legge til rette for like konkurransevilkår med utenlandsk industri. Siden meldingen ble lagt frem av Forsvarsdepartementet (FD) i oktober 2015, har det skjedd viktige endringer i de internasjonale rammebetingelsene for norsk forsvarsindustri. En av de viktigste er at Den europeiske union (EU) siden 2016 har satt i gang flere tiltak for å styrke EU som sikkerhetspolitisk aktør. Tiltakene utgjør EUs forsvarspakke og skal bidra til felles europeisk kapabilitetsutvikling for å styrke EUs operative evne. Målet er å oppnå "strategisk autonomi», som innebærer at EU blir i stand til å handle, helst sammen med partnere som Nato og USA, men om nødvendig også alene i militære operasjoner (Fiott, 2018; Howorth, 2019). Det betyr at EU og medlemsstatene må ta et større ansvar for egen sikkerhet.

Formålet med artikkelen er å bidra i kunnskapsbyggingen om EU som sikkerhets- og forsvarspolitisk aktør, og om hvordan Norge tilpasser seg denne utviklingen. På denne måten bidrar artikkelen til forskningslitteraturen om småstaters innflytelse i internasjonal politikk, og om overfor EU i særdeleshet (Cowles mfl., 2001; Olsen, 2002; Cooper, 2004; Sjursen, 2016). Artikkelen bidrar til ny forståelse av de mekanismene som preger Norges tilpasninger til europeisk integrasjon, nå som europeisk sikkerhet og forsvar ikke lenger bare er et mellomstatlig anliggende. Forskningsspørsmålene artikkelen svarer på, er følgende: Hva innebcerer EUs nye forsvarspakke? Hvordan og hvorfor har norske myndigheter og forsvarsindustri så langt håndtert de endringer som kommer som følge av denne?

For å kunne svare på forskningsspørsmålene tar vi et organisasjonsteoretisk utgangspunkt for å forklare hvordan og hvorfor Norge svarer som det gjør på EUs forsvarspakke. Ønsket om å forklare og forstå offentlige aktørers atferd gjør denne teoretiske tilnærmingen relevant. Med utgangspunkt i instrumentell og institusjonell teori (Christensen mfl., 2015) undersøker vi om Norges svar på forsvarspakken er relevante og tilstrekkelige for å ivareta norske interesser slik disse er nedfelt i stortingsmeldingen. Instrumentell teori forteller at aktørene handler formålsrasjonelt for å nå spesifiserte målsettinger. Institusjonelle teorier forteller at aktørene velger handlingsalternativer som passer med forventninger i organisasjonen og dens omgivelser.

Med bakgrunn i denne teoretiske tilnærmingen studerer vi norske myndigheters foretrukne veivalg og industriens interesser når det gjelder de nye EUinitiativene, og søker å forstå deres prioriteringer. Dette gjelder CARD (Coordinated Annual Review on Defence), som skal bidra til å koordinere nasjonale budsjetter og investeringer på forsvarsområdet, og permanent strukturert samarbeid (PESCO) for forpliktelser til kapabilitetsutvikling og operativt samarbeid. Av særlig stor betydning blir etableringen av det europeiske forsvarsfondet (European Defence Fund, EDF) fra 2021, som skal bidra til fellesfinansiering av forsvarsforskning og forsvarsmateriell 
for å rette opp kritiske kapabilitetsmangler i europeisk forsvar. Samlet skal disse initiativene sikre utbyggingen av et permanent rammeverk for et nærere europeisk forsvarssamarbeid, med mål om å legge grunnlaget for forsvarsintegrasjon og en europeisk forsvarsunion.

Utfordringen for Norge er at med CARD, PESCO og EDF på plass, vil ikke norsk forsvarsindustri lenger delta på like vilkår med øvrig europeisk industri. Dette vil særlig være tilfellet dersom Norge står utenfor deltakelse i PESCO og EDF. Norge vil i så fall stå utenfor de samarbeidsprosjekter som kommer som følge av forsvarspakken, både i form av konkrete PESCO-prosjekter og de finansieringsmuligheter som ligger i EDF. Dette kan utfordre nasjonale sikkerhetsinteresser. De viktigste argumentene for en nasjonal forsvarsindustri er hensynet til anskaffelseskompetanse, særnorske behov, følsomme områder og leveransesikkerhet. Satsing på innovasjon, teknologi og samarbeid er derfor avgjørende for å utvikle forsvarsindustrien. Slik satsing kommer det norske forsvaret til gode i form av materiell som er bedre tilpasset særnorske forhold, og en høyere kvalitet på tjenester som leveres (Meld. St. nr. 9 2015-2016, s. 5).

Artikkelen er organisert slik at neste kapittel tar for seg hovedtrekk ved instrumentell og institusjonell teori. Deretter redegiør vi for den metodiske tilnærmingen, der vi i stor grad har anvendt semistrukturerte intervjuer med norske myndigheter og forsvarsindustrien. Her diskuterer vi hvor representativt utvalget av intervjuobjekter er, og hvordan vi ved å triangulere mellom ulike kilder søker å oppnå høy grad av reliabilitet og validitet. For å besvare forskningsspørsmålene har vi delt den empiriske delen i to deler. I den første analyserer vi EUs initiativer og hva som kjennetegner EU som sikkerhetsaktør. Med utgangspunkt i denne analysen tar den andre delen for seg myndighetenes og den norske forsvarsindustriens utfordringer og muligheter slik disse blir uttrykt fra norske myndigheter og industrien selv. I den siste delen tar vi utgangspunkt i det teoretiske rammeverket, der vi undersøker myndighetenes og industriens strategiske veivalg. I denne analysedelen forklarer vi hvordan myndighetene og industrien så langt har tilpasset seg det som skjer på EU-siden. Vi kommer derfor med organisasjonsteoretisk begrunnede synspunkter på hvordan myndighetene kan legge vilkårene til rette slik at nasjonale sikkerhetsinteresser blir ivaretatt. Avslutningsvis summerer vi opp funnene og peker på nye problemstillinger som kan legge grunnlaget for fortsatt forskning på området.

\section{Instrumentelle og institusjonelle teorier og perspektiver}

Forsvarsmarkedet er unikt. Det er kjennetegnet av politisk regulering og bruk av andre virkemidler enn de som gjelder på det åpne markedet. Markedet er derfor ikke fritt slik økonomiske teorier forutsetter (Fevolden \& Tvetbråten, 2016). Forsvarsindustriens handlingsrom er definert av de begrensninger nasjonale myndigheter bestemmer, og av særskilte vilkår på det internasjonale markedet. Det europeiske markedet har derfor alltid vært et lukket marked. Norske myndigheters krav om internasjonalt materiellsamarbeid og gjenkjøp ved anskaffelser fra utenlandske bedrifter 
har tradisjonelt vært et effektivt virkemiddel for norsk eksport av forsvarsmateriell.Vi legger videre vekt på norske myndigheters atferd for å ivareta nasjonale sikkerhetsinteresser ved å opprettholde en nasjonal forsvarsindustri i fremtiden. Dermed blir det naturlig å anvende organisasjonsteori for offentlig sektor for å forklare deres svar på de utfordringer de nå står overfor.

Tilnærmingen vår tar utgangspunkt $\mathrm{i}$ instrumentelle og institusjonelle teorier og perspektiver. Instrumentelle teorier bygger på en forventning om at aktørene handler formålsrasjonelt ved å velge handlingsalternativer som er mest egnet for å realisere definerte målsettinger. Det betyr at myndighetene handler i tråd med en konsekvenslogikk ("logic of consequences») (March \& Olsen, 1989; March, 1991; March, 1994; Simon \& March, 1993). Det betyr at myndighetene definerer en målsetting som beskriver ønsket situasjon, vurderer mulige handlingsalternativer og forventede konsekvenser og til slutt tar avgjørelser i tråd med bestemte beslutningsregler (Christensen mfl., 2015, s. 34). Endringer i omgivelsene påvirker hvilke instrumenter og handlinger som er mest formålsrasjonelle (Christensen mfl., 2015, s. 45). Ut fra en konsekvenslogikk tilpasser derfor aktørene seg til sitt nære handlingsmiljø slik at de fortsatt kan nå sine mål (Christensen mfl., 2015, s. 45).

Instrumentelle teorier forventer at aktørene handler i tråd med definerte beslutningsregler i fire steg (Christensen, 2007, s. 22). Det første steget innebærer å definere målsettinger eller problemer, det vil si å bestemme hva som er ønsket situasjon og avstanden til denne. Det andre steget er å vurdere hvilke alternativer som er mulige. Det tredje steget er å beregne forventede virkninger i forhold til målsettingene, altså å vurdere fremtidige virkninger for hvert av alternativene og sannsynligheten for at de inntreffer. Det fjerde og siste steget viser til beslutningsregler, altså valget mellom de ulike alternativene (Christensen, 2007, s. 22).

Fra et instrumentelt perspektiv antas aktørene å ha evne til rasjonell kalkulasjon og politisk kontroll (Christensen mfl., 2015, s. 31; Scott \& Davis, 2016, s. 36). Det er i realiteten noen begrensninger i en slik evne. Organisasjoner har ofte uklare, motstridende og flytende målsettinger som er vanskelige å håndtere (Christensen, 2007, s. 23). Aktørene har også begrenset kapasitet når det gjelder å skaffe informasjon om alternativer og konsekvenser (Christensen, 2007, s. 23). Det betyr at aktørenes informasjonstilgang påvirker deres beslutningsgrunnlag. Videre har deres organisatoriske tilhørighet og plassering i organisasjonen betydning for deres interesser og kapasitet i beslutningsprosessen. Instrumentelle teorier viser derfor ofte til begrenset rasjonalitet for å forklare og forstå aktørenes handlinger.

Fra et instrumentelt perspektiv forventer vi dermed følgende svar fra norske myndigheter på EUs forsvarspakke:

Myndighetene folger formålsrasjonelle beslutningsregler og velger de virkemidlene de anser som mest effektive for å sikre norsk forsvarsindustri like vilkår i fremtiden.

Institusjonelle teorier og perspektiver forventer at aktørene handler i tråd med en logikk om det passende ("logic of appropriateness»), slik at handlingene har legitimitet 
(March \& Olsen, 1989; March, 1994; March, 1991; March \& Olsen, 1996; Simon \& March, 1993). Legitimitet innebærer at myndighetenes handlinger er i henhold til lov eller blir ansett for å være rettmessige og rettferdige.

Som Christensen mfl. (2009, s. 13-14) skriver, har organisasjonene egne institusjonelle regler, verdier og normer. Det gjør at de har en selvstendig innflytelse på beslutningstakerne, og de tilpasser seg ikke skiftende styringssignaler like enkelt som instrumentell teori forventer. Institusjonelle teorier skiller videre mellom et kulturog et myteperspektiv. Innenfor et kulturelt perspektiv svarer myndighetene i tråd med etablerte normer, rutiner og prosedyrer. Det vil si at erfaringer med det gjeldende virkemiddelapparatet påvirker aktørenes atferd.

Fra et kulturperspektiv forventer vi dermed følgende svar fra norske myndigheter:

Myndighetene svarer $i$ tråd med tidligere veivalg når EU har fattet avgjørelser på det sikkerhets- og forsvarspolitiske området. Det vil si at de ser til tidligere fungerende losninger.

Myteperspektivet legger til grunn at aktørene tilpasser seg forventninger i omgivelsene. Myteperspektivet er dermed en mer åpen modell der aktørene søker akseptable handlinger i tråd med organisasjonens omgivelser. Organisasjonene søker derfor utover og følger sosialt konstruerte normer for å oppnå legitimitet innenfor sitt miljø, uavhengig av om disse er effektive eller ikke. Det som er viktig, er at normene har legitimitet hos andre. Ettersom normene er sosialt konstruerte verdier, blir de ofte omtalt som myter eller symboler (Christensen mfl., 2009, s. 13-14). Når flere organisasjoner følger og tilpasser seg de samme mytene, utvikler de over tid en organisatorisk likhet. En slik utvikling står dermed i kontrast til et kulturperspektiv, som forventer at organisasjoner søker innover og styrker sin interne kultur (Christensen mfl., 2009, s. 13-14).

Fra et myteperspektiv forventer vi dermed følgende svar fra norske myndigheter:

Myndighetene tilpasser seg EU-institusjonene og medlemsstatene. Det betyr at myndighetene avventer utviklingen på EU-siden for de svarer $i$ tråd med forventningene der.

Disse teoretiske retningene gir derfor ulike forventede svar på hvordan norske myndigheter skal forholde seg til et EU som tar økt sikkerhets- og forsvarspolitisk ansvar. Dette krever imidlertid kunnskap og perspektiver om hva slags sikkerhets- og forsvarspolitisk aktør EU er. Det er ut fra en slik beskrivelse vi blir i stand til å forstå de strategiske veivalg norske myndigheter tar.

\section{Det metodiske grunnlaget}

Empirien bygger på en kildetriangulering der vi beveger oss mellom egeninnsamlede primærkilder og sekundærkilder. Den empiriske analysen er delt i to deler, der den første tar for seg utviklingen av EU som sikkerhetspolitisk aktør etter 2016. Denne analysen bygger på sekundærkilder, der den viktigste er eksisterende forskningslitteratur på området. Dette legger grunnlaget for den empiriske analysens andre del, 
som tar for seg myndighetenes og forsvarsindustriens svar på EUs nye politikk på det sikkerhets- og forsvarspolitiske området.

Den empiriske analysens andre del bygger derfor på semistrukturerte intervjuer med sentralt plasserte representanter fra norske myndigheter og forsvarsindustri som arbeider med tilpasningen til EUs forsvarspakke. Intervjuene ble foretatt i tidsrommet oktober-november 2018. Vi gjennomførte i alt ti intervjuer med 15 personer (se appendiks A). Fra myndighetssiden intervjuet vi personell i FD, Forsvarets forskningsinstitutt (FFI), Norges EU-delegasjon i Brussel og i Europakommisjonen. Fra industrisiden intervjuet vi personell ved Forsvars- og sikkerhetsindustriens forening (FSi), Kongsberg Defence and Aerospace AS (KDA), Nammo AS, Rheinmetall Norway AS og Thales Norway AS. Bedriftene er interessante av flere årsaker. Blant annet omfatter utvalget norskeide og utenlandskeide bedrifter. Bedriftene utgjorde tidligere de fire største forsvarsbedriftene i Norge, ofte omtalt som «de fire store». KDA og Nammo er fortsatt de to største i Norge. Selv om de andre bedriftene ikke lenger er rangert på de neste to plassene, har samtlige bedrifter fortsatt leveranser som er viktige for norsk sikkerhet. Vi mener at intervjuer med nøkkelpersoner fra disse bedriftene og FSi gir den informasjonen som er representativ for norsk forsvarsindustri. Personene vi intervjuet, satt alle sentralt i sine respektive organisasjoner, og for tre av organisasjonenes vedkommende fikk vi intervjue lederne av disse. Disse har myndighet til å fatte avgjørelser på sine organisasjoners vegne når det gjelder tilpasningene til EUs forsvarspakke. Dette er med på å styrke både validiteten og reliabiliteten av våre funn.

Forventningene vi har til den informasjonen vi samler inn, er slik at de opplysningene vi får fra myndighetene, er mest relevant for å svare på hvilke konsekvenser EU-initiativene får for norsk forsvarsforskning- og forsvarsindustripolitikk, mens informasjonen fra forsvarsindustrien best svarer på hvilke tilpasninger myndighetene kan gjøre for å opprettholde en nasjonal forsvarsindustri. Under intervjuene stilte vi følgende tre spørsmål: Hvor godt kjenner dere til de nye EU-initiativene på sikkerhet og forsvar? Vil de ha betydning for dere, og i så fall hvilke konsekvenser? Hvordan kan norske myndigheter legge forholdene til rette for at norsk forsvarsindustris interesser blir ivaretatt?

Spørsmålene er valgt for å få informasjon om hvor godt de har satt seg inn i forsvarspakken, mulige virkninger for norsk forsvarsindustri og hvordan myndighetene bør svare. Spørsmålene er av overordnet karakter fordi norske myndigheters og forsvarsindustris tilpasning til forsvarspakken er av helt ny dato. Dette gjør at en slik eksplorativ metode er helt nødvendig for å kunne skaffe oss ny innsikt på et område som det ikke har vært forsket på tidligere.

\section{EU som sikkerhets- og forsvarspolitisk aktør}

EU representerer en helt spesiell form for styring i internasjonal politikk ved at medlemsstatene er villige til å delegere makt og myndighet til overnasjonale institusjoner. 
Sikkerhets- og forsvarspolitikken har imidlertid vært unntatt fra den europeiske integrasjonsprosessen og således vært underordnet nasjonal suverenitet (Moravcsik, 1998; Menon, 2013).

Dette er nå i endring. EU har satt som mål å styrke sin strategiske autonomi for å forsvare og beskytte vitale europeiske sikkerhetsinteresser i tråd med EUs globale strategi fra juni 2016 (EU, 2016). Bakgrunnen er endrede sikkerhetspolitiske omgivelser, som statssammenbrudd i Europas geografiske nærhet, Russlands mer aggressive utenrikspolitikk, brexit og USAs manglende ledervilje (Biscop, 2017a, 2019; Fiott, 2018; Melby, 2017).

Et mer integrert EU på det utenriks- og sikkerhetspolitiske området betyr at også dette området omfattes av europeisk integrasjon (Olsen, Rosén \& Trondal, 2016). Som følge av dette oppstår en ny plattform hvor institusjoner, regler og prosedyrer på europeisk og medlemsstatsnivå koples tettere til hverandre. I et slikt perspektiv bidrar EU-initiativer som CARD, PESCO og EDF til å knytte de intergovernmentale og de overnasjonale nivåene av integrasjonsprosessen enda nærmere hverandre. Slik ser vi utviklingen av et institusjonelt landskap hvor administrative enheter på nasjonalt nivå koples sammen med tilsvarende enheter på EU-nivå. For eksempel legger medlemsstatene gjennom CARD og PESCO premissene for vedtatte prosjekter, mens Europakommisjonen gjennom EDF bidrar med finansiering. Europakommisjonen får følgelig innflytelse på utformingen og iverksettingen av EUs felles utenriks- og sikkerhetspolitikk (FUSP) i samspill med medlemsstatene.

Utfordringen for Europakommisjonen og medlemsstatene er at mye av forsvarsforskningen og -anskaffelsene hittil har vært et nasjonalt ansvar alene. Etter finanskrisen trakk EU-landene seg ytterligere tilbake til sine nasjonale arenaer (EUISS, 2016, s. 32-34). Tall fra Det europeiske forsvarsbyrået (EDA, 2014) viser at de anvendte en marginal del av sine forsvarsbudsjetter på fellesprogrammer. I 2014 brukte medlemsstatene 4,7 milliarder euro på flernasjonale anskaffelsesprogrammer, hvorav 4,5 milliarder euro var europeiske. Samme år brukte de 0,2 milliarder euro på flernasjonale forsvarsforskningsprogrammer (forskning og teknologi, R\&T), hvorav 0,16 milliarder euro var europeiske. Til sammenligning utgjorde norsk forsvarsforskning om lag to milliarder kroner i 2017, som for det meste er nasjonalt finansiert over offentlige budsjetter og av industrien. Til tross for fordeler med samarbeid er det i dag færre slike felles anskaffelsesprogrammer enn det var for ti år siden.

Det europeiske forsvarssamarbeidet er derfor fortsatt i ubalanse. De europeiske medlemsstatene i EU og Nato samarbeider riktignok med hverandre i internasjonale operasjoner, men de anskaffer materiell og planlegger for militære operasjoner på nasjonal basis (Valášek, 2011). Ubalansen kommer til uttrykk i form av at det blant de europeiske Nato-allierte finnes 178 ulike våpensystemer, mens USA bare har 30. I Europa finnes 17 ulike stridsvogntyper, mens USA bare har én. Dessuten har Europa 29 ulike typer destroyere og fregatter, mens USA har fire. Av kampfly har Europa 20 ulike typer, mens USA har seks (IISS, 2017; SIPRI, 2017; Munich Security Report, 2017). 
Dette har en kostnad i form av kritiske kapabilitetsmangler i europeisk forsvar. Kapabiliteter mangler innenfor områder som luft-til-luft-tanking samt felles etterretning, overvåking og rekognosering (Joint ISR). Europa er derfor avhengig av USA for å kunne gjennomføre større operasjoner, som i Libya i 2011 (Hallams \& Schreer, 2012).

Forsvarspakken skal derfor bidra til å rette opp slike ubalanser. CARD skal identifisere europeiske kapabilitetsmangler med utgangspunkt i EUs kapabilitetsutviklingsplan (CDP) og vil være en overbygning over de ulike initiativene. CARD ble virksom i 2019, og målet er å bidra til en bedre utnyttelse av medlemsstatenes forsvarsbudsjetter og investeringsplaner ved å identifisere mulige samarbeidsprosjekter (EU, 2017; Fiott, 2017). ${ }^{1}$ Slik skal de sikre en gradvis synkronisering og gjensidig tilpasning av nasjonal forsvarsplanlegging og kapabilitetsutvikling (EU, 2016). Det vil riktignok ta tid å utvikle potensialet i CARD fullt ut, siden medlemsstatene fremdeles har ulike prioriteringer (Fiott, 2018, s. 1).

PESCO er traktatfestet i Lisboa-traktaten og styrt av medlemsstatene. Formålet er å fordype forsvarssamarbeidet ved å utvikle kapabiliteter og gjøre disse tilgjengelige for EUs militære operasjoner. Forskjellen mellom PESCO og andre former for forsvarssamarbeid er den forpliktende formen for samarbeid PESCO er (Biscop, 2018). De 25 medlemsstatene som deltar i PESCO, har nå 20 ulike forpliktelser, og disse kom til uttrykk i en notifikasjon fra medlemsstatene til EUs råd og høyrepresentanten for den felles utenriks- og sikkerhetspolitikken (HR/VP) i desember 2017 (Juncker, 2016; Juncker, 2017; EU, 2017; EU, 2018a). ${ }^{2}$ Blant disse forpliktelsene er deltakelsen i minst ett PESCO-prosjekt som medlemsstatene skal finne "strategisk relevant». I første omgang vedtok deltakerne etableringen av 17 PESCO-prosjekter som omfattet alt fra etableringen av European Medical Command til EU Training Mission Competence Centre (EU, 2018a). 20. november 2018 vedtok EUs råd en ny liste med ytterligere 17 PESCO-prosjekter, blant annet et prosjekt på European Attack Helicopters TIGER og et prosjekt på utviklingen av europeiske dronekapasiteter (Eurodrone) (EU, 2018b). Målet er at slike prosjekter får strategiske effekter ved at de reduserer viktige europeiske kapabilitetsmangler.

Forpliktelsene som PESCO innebærer, kommer til uttrykk ved at hver enkelt deltakerstat årlig må redegjøre for sine bestrebelser i en National Implementation Plan (NIP). Slik skal PESCO bidra til en bedre balanse i europeisk forsvar, samtidig som EU opprettholder beslutningsautonomien på det sikkerhets- og forsvarspolitiske området. ${ }^{3}$

PESCO skal også legge grunnlaget for et forbedret samarbeid mellom EU og Nato i kraft av forpliktelsen om militær mobilitet. Europakommisjonen foreslår å

\footnotetext{
${ }^{1}$ Det europeiske forsvarsbyrået (EDA) skal sammen med EUs militære stab (EUMS) fungere som sekretariat for CARD.

${ }^{2}$ Danmark og Malta deltar ikke. Danmark kan ikke delta som følge av Edinburgh-kompromisset fra 1992, som unntar landet fra deltakelse i EUs forsvarssamarbeid. Malta deltar ikke på bakgrunn av landets nøytralitetsforpliktelser i sin grunnlov. Storbritannia meldte seg ut av EU 29. mars 2019. ${ }^{3}$ EDA og EUMS fungerer som sekretariat for PESCO.
} 
anvende 6,5 milliarder euro i tidsrommet 2021-2027 til dette European Connected Facility-programmet, som omfatter sivil-militære transportnettverk for å forbedre den militære mobiliteten innen EU. Militær mobilitet omhandler derfor en forenkling og standardisering av grensekryssende militær transport for å kunne sikre hurtig utplassering av militært materiell og personell. Dette er vesentlig for å sikre den kollektive forsvarsevnen.

PESCO dreier seg imidlertid ikke bare om kapabilitetsutvikling, men skal også styrke EUs operative evne ved å bringe deltakerlandenes forsvar mer på linje med hverandre. Det langsiktige målet er at deltakerstatene planlegger som om de hadde én felles militær evne, samtidig som den enkelte deltakerstat angir sitt eget bidrag. Forsvarspakken skal dermed sikre utviklingen av én felles styrkepakke (Biscop, 2017a, s. 7).

PESCO og forsvarsfondet (EDF) skal også bidra til å styrke den europeiske forsvarsteknologiske industribasen (EDTIB). Oppgaven til forsvarsfondet blir derfor å bidra til finansiering av prosjekter der fondet kan bidra med opptil 30 prosent av utviklingskostnadene for PESCO-prosjekter. Det innebærer å bidra til felles investeringer i forskning og utvikling av forsvarsmateriell og teknologier.

Som en forløper for dette fondet har EU vedtatt en forordning om å etablere et European Defence Industrial Development Programme (EDIDP) fra $2019 \mathrm{og}$ frem til etableringen av EDF i 2021. Formålet med EDIDP og EDF er å bidra til finansiell støtte til forsvarsindustrien i utviklingsfasen av nye produkter og teknologier på områder som blir utvalgt på det europeiske nivået. EDIDP og det senere EDF vil følgelig støtte medlemsstatene i utviklingen av forsvarsmateriell og teknologi. Anskaffelser av militært utstyr og teknologi er utenfor programmet. Derfor understreker EU selv at hensikten er å fylle gapet mellom forsknings- og produksjonsfasene (Europaparlamentet, 2018).

Forsvarsfondet har tre mål. For det første skal det fremme forsvarsindustriens konkurranseevne og innovasjonskapasitet. For det andre skal det støtte og utnytte samarbeidet mellom bedrifter, herunder små og mellomstore bedrifter, og for det tredje skal det fremme bedre utnyttelse av resultatene av forsvarsforskningen som ligger til grunn for all kapabilitetsutvikling (Europaparlamentet, 2018). I årene mellom 2021 og 2027 har Europakommisjonen foreslått å bevilge i alt 13 milliarder euro til EDF. Sammen med bidrag fra medlemsstatene til utviklingen av felles utviklingsprosjekter skal EDF kunne generere en investering i forsvarsforskning og kapabilitetsutvikling på i alt 5,5 milliarder euro årlig fra og med 2021. Det er derfor viktig å betrakte CARD, PESCO og EDF som en helhetlig forsvarspakke som både skal styrke EU som sikkerhetsaktør og bidra til EUs autonomi på det sikkerhets- og forsvarspolitiske området.

\section{Konsekvenser for norsk forsvarsindustri}

I 2017 eksporterte norsk forsvarsindustri A- og B-materiell til Europa for om lag 1,6 milliarder kroner, tilsvarende om lag 30 prosent av samlet eksport for disse 
varekategoriene (Meld. St. nr. 19 2017-2018). ${ }^{4}$ Både eksport og teknologioverføring fra utenlandske bedrifter er viktig for å ivareta en nasjonal høyteknologisk forsvarsindustri. Konsekvensene kan bli store hvis norske bedrifter og forsvarsforskningsmiljøer blir stående uten tilknytning til EUs forsvarspakke.

Kjennskap til og kunnskap om de nye EU-initiativene

Intervjuene viser en svært heterogen kjennskap til og kunnskap om de nye EUinitiativene. Et av våre viktigste funn er at dette gjelder både på myndighetssiden og blant forsvarsbedriftene. Norge har representanter ved EU-delegasjonen i Brussel og nasjonal ekspert i Europakommisjonen som følger utviklingen på EU-siden tett. I særlig grad har myndighetene god kjennskap til og kunnskap om EDF, og om den betydning dette vil kunne få for europeisk så vel som for norsk forsvarsindustri. Når det gjelder CARD, har de noe mer begrenset interesse, siden dette er mindre relevant for Norge. Når det gjelder PESCO, er kjennskapen og kunnskapen fragmentert. I første rekke prioriterer myndighetene PESCO-forpliktelsen om militær mobilitet fordi dette også bidrar til å styrke Natos kollektive forsvarsevne (Intervju 7 og 8).

Våre samtaler med norsk forsvarsindustri viser ikke bare en fragmentert kunnskap om og kjennskap til EU-initiativene, men også ulik tilnærming til hvordan de oppfatter EUs forsvarspakke. Samtalene med industrien viser at de har begrenset kunnskap om og interesse av CARD og EDF. Det er imidlertid stor variasjon mellom bedriftene, og noen er svært engasjert når det gjelder aktiviteter knyttet til PESCO. KDA viser stor kunnskap om og kjennskap til initiativene og utarbeider samtidig en strategi på området. Strategien innebærer etableringen av en stilling i Norway House i Brussel. Slik skal KDA kunne følge utviklingen på EU-siden tett. Ingen av de andre bedriftene eller bransjeorganisasjonene forbereder så langt en tilsvarende permanent tilstedeværelse (Intervju 1).

Samlet sett viser våre intervjuer delvis informasjonsutveksling mellom myndighetene og industrien samt industribedriftene seg imellom. De vet derfor hvilke bedrifter som er positive til EU-initiativene, og hvilke som prioriterer nasjonale eller ikke-europeiske markeder. Det er derimot varierende informasjonsflyt mellom myndighetene og industrien samt mellom bedriftene når det gjelder strategiplaner.

Flere av intervjuobjektene antar at andre bedrifter har kommet lenger i strategiarbeidet enn det de faktisk har. Dette er overraskende, siden flere av bedriftene er monopolister eller oligopolister nasjonalt. I Norge er det et tett samarbeid mellom myndighetene og industrien. ${ }^{5}$ Dette har vært viktig for utviklingen av flere norske

\footnotetext{
${ }^{4}$ Eksport av varer som er klassifisert som A- og B-materiell i henhold til Utenriksdepartementets lister. A-materiell er våpen, ammunisjon og visse typer militært materiell. I tillegg omfattes annet materiell med strategisk kapasitet som vesentlig kan påvirke de militære styrkeforhold i nærområdet. B-materiell omfatter øvrige forsvarsrelaterte varer som ikke har egenskaper eller bruksområder som definert for varekategori A (Meld. St. nr. 19, 2017-2018, s. 5).

5 Dette trepartssamarbeidet blir innenfor forsvarssektoren ofte omtalt som et trekantsamarbeid mellom Forsvaret, forskningsmiljøene (i første rekke FFI) og industrien.
} 
forsvarsprodukter, som Naval Strike Missile (NSM), Penguin-missilet, antiubåtsystemet Terne, våpenstasjonen Protector (RWS) med flere (Intervju 4). Våre funn viser at dialogen mellom partene når det gjelder EUs forsvarspakke, ikke er så tett som trepartssamarbeidet tilsier.

\section{Betydning og konsekvenser}

Myndighetene prioriterer i første rekke forsvarsfondet på bakgrunn av de muligheter som ligger i det for norsk forsvarsindustri (Intervju 7 og 8). Myndighetssiden understreker at det er av avgjørende betydning for Norge å delta i EDF fra 2021. Norge er da også invitert av EU til å delta i fondet fra dette tidspunktet. Den formelle beslutningen om norsk deltakelse i EDF er ennå ikke fattet. Hvis Norge velger å delta, blir det norske bidraget på 2,8 milliarder kroner over sjuårsperioden frem til og med 2027. Myndighetene er tydelig på at bidraget til fondet er et pokerspill, der det er usikkert hvor mye Norge får tilbake i form av bevilgninger til forsvarsforskning og kapabilitetsutvikling (Intervju 8).

Det betyr at norske myndigheter erkjenner EUs økende betydning som sikkerhets- og forsvarspolitisk aktør. Det gjør også industrien, selv om de har ulikt syn når det kommer til hvilken betydning og konsekvenser det vil ha. Motivet som ligger til grunn for politikkutformingen, er at norsk industri skal ha de samme rammebetingelsene som den øvrige europeiske forsvarsindustrien. Samtidig er myndighetssiden klar på at PESCO og EDF kan bli viktige og få stor strategisk relevans for europeisk forsvarssamarbeid. Det er derfor viktig at Norge posisjonerer seg nå, samt at myndighetene og industrien samarbeider for å finne relevante prosjekter som ivaretar Norges sikkerhetspolitiske og økonomiske interesser.

Selv om norske myndigheter ser viktigheten av forsvarspakken, har de moderate forventninger til de 34 PESCO-prosjektene som så langt er vedtatt (Intervju 7 og 8). Bakgrunnen er det de anser som manglende strategiske effekter av prosjektene. Myndighetssiden vektlegger at oppdelingen i små prosjekter med mange deltakerland ikke er optimalt. I stedet foretrekker de færre, men større prosjekter som bedre dekker grunnleggende kapabilitetsmangler og -behov. Det betyr at norske myndigheter ønsker at EUs forsvarspakke lykkes gjennom ambisiøse PESCO-prosjekter.

Det er imidlertid uenighet mellom bedriftene når det gjelder hvilke betydninger og konsekvenser EUs forsvarspakke får. En av bedriftene ser at EUs institusjoner får økende betydning for utformingen av europeisk sikkerhets- og forsvarspolitikk, noe som KDA forholder seg aktivt til gjennom permanent tilstedeværelse i Brussel (Intervju 1). Om det er fordelaktig for KDA, gjenstår imidlertid å se. Denne strategien står $\mathrm{i}$ kontrast til de andre bedriftene og har sin årsak $\mathrm{i}$ at de konkurrerer i forskjellige forsvarsmarkeder. Det er lite å hente fra de nye EU-initiativene for bedrifter som leverer produkter der det ikke er naturlig med internasjonalt samarbeid, som ferdigutviklede nisjeprodukter eller høygradert materiell til det norske forsvaret (Intervju 3). Derfor har de bevisst valgt en mer avventende strategi uten noen foreløpig tilstedeværelse i Brussel. 
En av bedriftene viser også en negativ holdning til EUs forsvarspakke, siden de anser et "velfungerende EU som et skrekkscenario» (Intervju 6). Dette gjelder spesielt PESCO, der de håper at denne formen for samarbeid fortsetter som småprosjekter uten strategisk effekt. De «heier på fiasko». Dette har sin bakgrunn i at PESCO primært gir insentiver til underleveranser innenfor EU. EU-initiativene kan derfor anses som uheldige for norsk forsvarsindustri, som nesten utelukkende er underleverandører. Industrien er imidlertid uenig på dette punktet. En av bedriftene mener at det å legge seg på 34 PESCO-prosjekter med et moderat ambisjonsnivå, er fornuftig, ettersom det kan sikre suksess på kort sikt (Intervju 3). Tidlig suksess er ofte en forutsetning for mer ambisiøse prosjekter på lengre sikt. Andre bedrifter støtter deler av myndighetenes oppfatning om at færre, men større prosjekter hadde vært mer fordelaktig.

Samtalene våre viser at bedriftene ikke ønsker å bære risikoen for deltakelse i EU-prosjekter selv. Så langt har de hatt dårlige erfaringer med deltakelse i det forberedende forsvarsforskningsprogrammet (Preporatory Action on Defence Research; PADR) og i Horizon 2020 (Intervju 4). Hvis Norge ikke får noe tilbake nå, mener flere av bedriftene at dette bare er penger ut av vinduet. En av informantene understreker at EUs initiativer så langt har fungert bedre politisk enn industrielt, og at kommisjonspresidenten Jean Claude Juncker bygger et nytt luftslott gjennom forsvarspakken (Intervju 5).

Industrien understreker derfor at verken myndighetene eller industrien ennå vet fullt ut hva som blir de konkrete resultatene av EUs forsvarspakke (Intervju 2). Alt er i sin spede begynnelse, og det vil ta noen år før man vet hva betydningen blir for EUs sikkerhets- og forsvarspolitikk og den europeiske forsvarsindustrielle teknologibasen. I denne sammenhengen er norske forsvarsbedrifter relativt små aktører på det internasjonale markedet. Norge er opptatt av at EU bygger opp en balansert teknologibase for å unngå en situasjon der de store forsvarsbedriftene blir stadig større og de mindre blir borte. Dette er spesielt viktig dersom muligheten for industrisamarbeid blir ytterligere begrenset. EUs direktiver for anskaffelser og intra-transfer har allerede satt i gang en prosess i denne retningen (EU, 2009a; EU, 2009b; Strikwerda, 2017; 2018). Europakommisjonen og EU-domstolen har allerede innskrenket omfanget av medlemsstatenes henvisninger til unntaksmulighetene i Lisboa-traktaten (TFEU artikkel 346). Det er imidlertid tolkningsrom i regelverket som viser betydningen av myndighetenes evne og vilje til tilrettelegging.

Tilrettelegging fra norske myndigheter

Våre funn viser at myndighetene er usikre på om de skal gå i retning av bilaterale avtaler, eller om de skal prioritere EU i tiden som kommer. Intervjuene forteller at de forsøker å giøre begge deler samtidig (Intervju 7 og 8). Myndighetene forteller at de så langt satser på bilaterale avtaler med nære samarbeidspartnere. Bilaterale avtaler med landene rundt Nordsjøen har vært en viktig strategi for Norge siden 2002. Tyskland er en særlig interessant aktør, både som Europas sentralmakt og som 
en stabil og forutsigbar partner (Ekspertgruppen, 2015, s. 43). Norge og Tyskland undertegnet $i$ august 2017 en avtale om et strategisk samarbeid om maritimt forsvarsmateriell, som nye ubåter og sjømålsmissiler (Regjeringen, 2017). Våre intervjuer med myndighetene bekrefter viktigheten av bilaterale avtaler også i tiden fremover.

Tidligere erfaringer viser at det er bedre med bilaterale avtaler med mindre budsjetter og klare forpliktelser, enn multilaterale avtaler med langt større budsjetter der det er usikkert hvor mye Norge får igjen (Intervju 8). Dette har så langt gjort seg gjeldende for PADR-prosjektene. Samtidig er myndighetene positivt avventende til forsvarspakken og især PESCO og EDF. De følger utviklingen tett og ønsker ikke å lukke noen dører. Norske myndigheter tror heller ikke at dørene vil være stengt. Selv om tredjeland kun unntaksvis får delta i PESCO-prosjekter, forventer de å finne pragmatiske løsninger som gjør at Norge får delta (Intervju 10). Myndighetene bekrefter at det er viktig at Norge får en fot innenfor PESCO. Dette viser at norske myndigheter erkjenner den økonomiske risikoen som er forbundet med å bidra med tilskudd til EDF (Intervju 7, 8 og 10). Her ligger det et potensial for tap, men dette er et tap myndighetene aksepterer. Dette bekrefter Norges interesse av full deltakelse i utviklingen av den europeiske forsvarsindustrielle teknologibasen, som ikke utelukker bilaterale samarbeidsarrangementer (Intervju 7 og 8).

Industrien understreker nødvendigheten av at Norge blir knyttet til forsvarspakken. I motsatt fall risikerer norsk forsvarsindustri å dø innen tjue år (Intervju 5). Selv om ikke alle bedriftene har like pessimistisk syn, viser det hvilken betydning EUs forsvarspakke har for norsk forsvarsindustri.

Vi gjør også en interessant observasjon om at industrien deler det samme synet seg imellom - og med myndighetene - når det gjelder myndighetenes tilpasninger. Et av områdene som utpeker seg, er intellektuelle eiendomsrettigheter (IPR), som omhandler industrielle rettigheter og åndsverk (Intervju 9). Flernasjonale forsvarsutviklingsprosjekter reiser særegne utfordringer, spesielt på grunn av sensitive teknologier som angår hver enkelt stats nasjonale sikkerhet. Dette er en utfordring når flernasjonalt samarbeid skal sikre håndtering og prioritering av viktige kapabilitetsmangler innenfor europeisk forsvar (EUISS, 2016, s. 22).

I denne sammenhengen understrekes det fra Europakommisjonens side at industrien fortsatt vil eie, kontrollere og beholde IPR (Intervju 9). Her vil riktignok Europakommisjonen kunne benytte seg av forskningsresultatene på ikke-kommersielt grunnlag. Der man imidlertid ser en viss grad av tvetydighet, er i kontrollen over IPR på den ene siden og i landenes kompetanse på eksportkontroll på den andre. Europakommisjonen understreker at ved konflikt skal IPR forbli innenfor EU. Dette har allerede skapt konflikt i forholdet til USA, men også i forholdet til Storbritannia som et tredjeland.

Norge vil i denne sammenhengen ikke være et tredjeland, men et assosiert land. Det betyr at fondet vil være åpent for Norge, også når det kommer til IPR. Her vil det imidlertid være en særegen utfordring knyttet til utveksling av gradert informasjon, men dette er noe som Norge og Europakommisjonen vil finne en praktisk 
løsning på innenfor rammen av EDF. Dette vil imidlertid være en utfordring i det neste forskningsprogrammet Horizon Europe, der Norge ikke har fått en tilsvarende avtale. Slik får Norge en bedre avtale med EDF enn med Horizon Europe.

\section{Strategiske veivalg for norsk forsvarsindustri}

En sentral utfordring for norsk forsvarsindustri er at den kan miste markedsandeler som følge av forsvarspakken. Fra et instrumentelt perspektiv kan dermed et problem for norske myndigheter og industrien være den oppfattede avstanden mellom en ønsket og faktisk tilstand (Christensen mfl., 2015, s. 32). Den ønskede tilstanden er at norsk forsvarsindustri har de samme rammebetingelser på det europeiske forsvarsmarkedet som den øvrige europeiske industrien. I en slik situasjon forventer vi at norske myndigheter har klare forestillinger om hvilke utfordringer Norge møter, og at de søker å løse dem ved hjelp av virkemidler som har tilstrekkelig forventet effekt. Norske myndigheter kan dermed se på hvilke handlingsmuligheter som foreligger. Slik vi ser det, er det to muligheter. Den ene muligheten er å styrke det bilaterale materiellsamarbeidet med utvalgte europeiske stater, som Tyskland. Den andre muligheten er å søke innflytelse gjennom Europakommisjonen på bakgrunn av Kommisjonens økende innflytelse over EUs sikkerhets- og forsvarspolitikk (CSDP). Det instrumentelle perspektivet forventer at norske myndigheter velger de virkemidlene de anser som effektive for å sikre norsk forsvarsindustri like vilkår i fremtiden. Det kan være både bilaterale avtaler og forsvarspakken, avhengig av utviklingen i omgivelsene. Tysklands store innflytelse på utformingen av CSDP, og at landet kan påvirke både Frankrike og Europakommisjonen når sikkerhets- og forsvarspolitikken blir utformet, taler for bilaterale avtaler. Tilgang til forskningsresultater og europeisk forsvarsmarked taler for deltakelse i forsvarspakken. Det er beslutningsprosessen i forkant som avgiør om myndighetene handler instrumentelt eller ikke.

Våre intervjuer med myndighetene og industrien forteller at aktørene har en delvis instrumentell tilnærming til EUs nye initiativer. De har en klart definert målsetting om å sikre like spilleregler for forsvarsindustrien når tradisjonelt industrisamarbeid blir mer begrenset. Målsettingen samsvarer med industriens ønsker. De vurderer to mulige handlingsalternativer: bilaterale avtaler og deltakelse i EUs forsvarspakke. For hvert av alternativene veier de kostnadene ved å delta opp mot farene forbundet med utestengelse. Myndighetene er villige til å gå inn som sponsorer for å sikre norsk deltakelse i forsvarspakken. Det er den høye risikoen sammenlignet med bilaterale avtaler som er mest problematisk (Intervju 8).

Våre funn viser at myndighetene og industrien fatter beslutninger på grunnlag av fragmentert kunnskap og forståelse. Forventningen om begrenset rasjonalitet sier at aktørene kun tar hensyn til relevant informasjon. Det er likevel vanskelig å si at aktørene svarer instrumentelt når de ikke kjenner til innholdet $i$ hele EUs forsvarspakke. Dette kommer særlig til uttrykk ved at myndighetene i liten grad vektlegger mulige gevinster ved deltakelse. For eksempel legger de ikke vekt på at Norge 
som deltaker i PADR får tilgang til alle forskningsresultatene fra dette forberedende programmet. De ser heller ikke på helheten i forsvarspakken som et effektivt virkemiddel for å sikre forsvarsindustrien like vilkår i fremtiden.

Forsvarsindustrien uttrykker et tilsvarende fragmentert beslutningsgrunnlag og usikkerhet om mulige gevinster. Det at norsk industri ikke har kommet så langt i utarbeidelsen av strategier, er et uttrykk for en avventende holdning til betydningen av EU-initiativene. Bedriftenes vansker med å posisjonere seg er en naturlig reaksjon på usikkerheten knyttet til hvilken betydning EU-initiativene faktisk vil ha for norsk forsvarsindustri. Intervjuobjektene ser lite forretningsutvikling i EUs plandokumenter, og de synes det er vanskelig å forholde seg til forsvarspakken. Fra vår side vil vi gjerne understreke at en av de vesentligste utfordringene ligger hos norsk forsvarsindustri selv, som inntil nå ikke har prioritert tilstedeværelse i Brussel. Det er gjennom dag-til-dag-tilstedeværelse at nettverk blir bygget og nye industrimuligheter åpner seg (Intervju 9).

Våre intervjuer støtter derfor delvis instrumentelle forventninger. Norske myndigheter har kommet langt i forberedelsene når det gjelder EDF, selv om Regjeringen og Stortinget hittil ikke har avgjort om Norge skal delta.

Myndighetenes svar stotter dermed delvis det instrumentelle perspektivets forventninger. Myndighetene folger i stor grad formålsrasjonelle beshutningsregler og velger de virkemidlene de anser som mest effektive for å sikre norsk forsvarsindustri like vilkår i fremtiden.

Delvis støtte til instrumentelle teoriers forklaringskraft giør at vi også ser til institusjonelle tilnærminger for å forstå myndighetenes svar. Institusjonelle teorier, som vi har delt $i$ et kulturperspektiv og et myteperspektiv, antar at aktørene handler i tråd med en logikk om det passende. Fra et kulturperspektiv forstår vi at de handler i tråd med etablerte rutiner og prosedyrer når de holder fast ved tradisjonelt industrisamarbeid og en avventende holdning til EUs forsvarspakke. Våre intervjuer forteller at myndighetene søker legitimitet internt, både seg imellom og hos norsk forsvarsindustri. Intervjuene forteller også at myndighetene vektlegger tradisjonell norsk sikkerhetspolitisk orientering i beslutningsprosessen. Dette omhandler spesielt de praksiser og normer som har utviklet seg i relasjonene mellom Norge og EU siden 1994 (Eriksen \& Fossum, 2014). Således er de også med på å gi fortsatt legitimitet til Norges atlantiske orientering i sikkerhets- og forsvarspolitikken. Dette samsvarer med Norges nølende holdning og tilnærming til europeisk integrasjon (Frisvold, 2014).

Våre funn viser at frykten for å stå utenfor er den drivende faktoren i Norges tilnærming til EUs forsvarspakke. Samtidig er det en frykt, spesielt på myndighetssiden, for at EUs initiativer skal undergrave samholdet i Nato. Derfor forholder Norge seg til Natos forsvarsplanleggingsprosess og ikke til EUs kapabilitetsutviklingsplan (CDP) og CARD. Dette er noe som hovedsakelig angår medlemsstatene, og kunnskapen om dette området er derfor lavere enn den kunnskapen de har om PESCO og EDF. 
Dette er en utfordring for Norge. Siden CARD, PESCO og EDF skal bidra til å redusere europeiske kapabilitetsmangler, er norsk deltakelse med på å styrke EUs strategiske autonomi. Nytteverdien er at norsk forsvarsindustri kan utvikle mer kompetanse innenfor nye områder, noe som også bidrar til å ivareta nasjonale sikkerhetsinteresser. I tillegg får norske forsvarsbedrifter tilgang til det europeiske markedet på like vilkår. Dette viser til en viss grad spenningsforholdet mellom de instrumentelle og de kulturelle svarene Norge kan gi overfor EU.

Myndighetenes svar støtter dermed delvis kulturperspektivets forventninger. Myndighetene handler $i$ tråd med tidligere veivalg når EU fatter avgjørelser på det sikkerhets- og forsvarspolitiske området. Det vil si at de ser til tidligere fungerende løsninger.

Myteperspektivet forutsetter på sin side at myndighetene tilpasser seg intensjonene bak EUs forsvarspakke. I så fall kan ikke myndighetene forholde seg til forsvarspakken på en fragmentert måte. Det betyr at dersom myndighetene bestemmer seg for at Norge skal delta i et PESCO-prosjekt, må Norge, på lik linje med deltakerstatene, underskrive på de samme forpliktelsene. Her vil det ikke være plass til gratispassasjerer, noe som er viktig å ta i betraktning, fordi konkrete bidrag til noe som helst fra norsk side sitter svært langt inne. Det blir følgelig ingen særbehandling av Norge. Våre intervjuer støtter også i noen grad myteperspektivets forventninger ved at myndighetene også søker ekstern legitimitet hos EU i tråd med unionens forventninger. Dette betyr at jo mer EU integreres på det sikkerhets- og forsvarspolitiske området, desto mer vil Norge lene seg på EU for å sikre legitimitet for norske interesser. Samtidig benytter myndighetene i liten grad myter og symboler, slik at forklaringskraften er begrenset.

Myndighetenes svar støtter dermed $i$ liten grad myteperspektivets forventninger. Myndighetene tilpasser seg i liten grad EU-institusjonene og medlemsstatene. Myndighetene avventer videre i liten grad utviklingen på EU-siden for de svarer $i$ tråd med forventningene der.

På grunnlag av vår analyse vurderer vi at det instrumentelle perspektivet og kulturperspektivet er dominerende når norske myndigheter svarer på EU-initiativene. Myndighetene og forsvarsindustrien handler formålsrasjonelt ved å søke løsninger som opprettholder og videreutvikler norsk forsvarsforskning og forsvarsindustri. Samtidig vektlegger både myndighetene og bedriftene tidligere erfaringer, etablerte rutiner og prosedyrer når de begrunner sine forventninger og veivalg. Det er derfor av betydning at myndighetene og industrien innleder en større grad av dialog om hvordan Norge skal forholde seg til forsvarspakken. I tillegg er det av betydning at aktørene i Norge utvikler en tilstrekkelig forståelse for de prosesser som nå foregår på EU-siden.

Trusselen mot konsekvensene av å stå utenfor er høyst reell. Frankrike og Tyskland har allerede inngått avtaler om nye og store kapabilitetsprosjekter, som sjettegenerasjons kampfly (FCAS) og bakkebaserte kampsystemer (MGCS) (Sluttkommunike 
mellom Frankrike og Tyskland, 2017). Øvrig europeisk industri har ikke annet valg enn å knytte seg til. Alternativet er konkurs. Frankrike og Tyskland er imidlertid avhengig av at flere slutter seg til samarbeidet. De alene kan ikke nå den kritiske massen for et økonomisk bærekraftig prosjekt (Biscop, 2017a). Denne konsolideringsprosessen utfordrer norsk sikkerhets- og forsvarspolitikk. Myndighetene står derfor overfor et veivalg der de enten fortsetter å svare i tråd med et kulturelt perspektiv eller velger en mer instrumentell tilnærming.

\section{Avslutning}

Vår analyse forteller at et instrumentelt og et kulturelt perspektiv forklarer innretningen av Norges politikk med tanke på EUs forsvarspakke. En forsterkning av trepartssamarbeidet kan imidlertid danne grunnlaget for en enda sterkere instrumentell tilnærming. Mer kunnskap og kompetanse om forsvarspakken åpner for et mer formålsrasjonelt svar fra norske myndigheter. Selv om Norge beholder sin atlantiske orientering, er det av betydning å utvikle en mer helhetlig strategi overfor EU som samsvarer med intensjonene i forsvarspakken. Slik kan Norge bidra til å oppnå likere spilleregler for norsk forsvarsindustri i tråd med målsettingene i stortingsmeldingen om Norges forsvarsindustrielle strategi. I motsatt fall kan norsk forsvarsindustri tape markedsandeler $i$ et allerede krevende marked.

Utfordringen er hvordan Norge kan oppnå legitimitet overfor EU uten å bryte helt med nasjonalt etablerte normer. Integrasjonsprosessen omfatter nå det tradisjonelt mellomstatlige sikkerhets- og forsvarspolitiske samarbeidet. Den kommende European Peace Facility på 10,5 milliarder euro, som delfinansierer sivile og militære EU-operasjoner i årene 2021-2027, skal sammen med EDF og Connected European Facility-programmet bidra til å utvikle en større grad av strategisk autonomi.

Norge står i så fall overfor en ny sikkerhets- og forsvarspolitisk aktør. Derfor er det overraskende at ingen av våre intervjuobjekter omtalte EUs globale strategi (EU, 2016). Basert på våre intervjuer og analyser av foreliggende forskningslitteratur finner vi at Norge som tredjeland er mer avhengig av en strategi overfor EU enn mange av medlemsstatene.

En slik strategi krever mer forskning om organiseringen av trepartssamarbeidet mellom Forsvaret, FFI og industrien. Dette er særlig aktuelt i en tid der det bilaterale forholdet til Tyskland blir stadig viktigere, for eksempel på områder som nye ubåter og sjømålsmissiler. Samtidig øver landet svært stor innflytelse på utformingen av EUs sikkerhets- og forsvarspolitikk. Viktige forskningsspørsmål fremover blir derfor hvordan EUs forsvarspakke påvirker trepartssamarbeidet, der et fruktbart sammenligningsgrunnlag er hvordan Norge hittil har iverksatt de to forsvarsdirektivene som ble en del av norsk rett i 2014 (EU, 2009a; EU, 2009b; Strikwerda, 2017; Strikwerda, 2018). På denne måten blir man i stand til å vurdere betydningen av EUprosessens påvirkning på de praktiske sidene av norsk sikkerhets- og forsvarspolitikk. Som del av en slik analyse kan en casestudie om det bilaterale materiellsamarbeidet 
mellom Norge og Tyskland danne et empirisk grunnlag. Også i en slik studie vil anvendelse av instrumentelle og institusjonelle tilnærminger være et egnet utgangspunkt for analyse.

\section{Om forfatterne}

Kari Tvetbråten har mastergrad i statsvitenskap fra Universitetet i Oslo (UiO) med spesialisering innenfor offentlig politikk og administrasjon. Hun har over ti års erfaring som forsker ved Forsvarets forskningsinstitutt (FFI).

Bjørn Olav Knutsen har hovedfag i statsvitenskap fra Universitetet i Oslo. Han er i dag sjefsforsker ved Forsvarets forskningsinstitutt (FFI) og førsteamanuensis i statsvitenskap ved Nord universitet i Bodø.

\section{Referanser}

Biscop, S. (2017a). Oratio pro PESCO. Egmont paper 91. Brussel: Egmont.

Biscop, S. (2017b). European defence: What's in the CARDs for PESCO? Security policy brief 91. Brussel: Egmont Institute.

Biscop, S. (2018). European defence: Give PESCO a chance. Survival, 60(3), 161-180.

Chagnaud, M.-L., Mölling, C., Schütz, T. \& von Voss, A. (2017). Arming Europe: The state of the European technological and industrial base. I M.-L. Chagnaud, C. Mölling, T. Schütz \& A. von Voss, Arming Europe: The state of the European technological and industrial base (s. 53-65). Bonn: Dietz.

Christensen, T., Egeberg, M., Lægreid, P., Roness, P. G. \& Røvik, K. A. (2007). Organization theory and the public sector. Oxon: Routledge.

Christensen, T., Egeberg, M., Lægreid, P., Roness, P. G. \& Røvik, K. A. (2015). Organisasjonsteori for offentlig sektor. Oslo: Universitetsforlaget.

Cooper, R. (2004). The breaking of nations: Order and chaos in the twenty-first century. London, UK: Atlantic Books.

Cowles, M. G., Caporaso, J. \& Risse, T. (Red.) (2001). Transforming Europe. Europeanization and domestic change. Ithaca: Cornell University Press.

EDA (2014). EDTIB: EDA analysis of key trends. Brussel: Det europeiske forsvarsbyrå.

Ekspertgruppen for forsvaret av Norge (2015). Et felles løft. Hentet fra https://www.regjeringen.no/globalassets/ departementene/fd/dokumenter/et-felles-loft-webversjon.pdf

Eriksen, E. O. \& Fossum, J. E. (Red.) (2014). Det norske paradoks. Om Norges forhold til Den europeiske union. Oslo: Universitetsforlaget.

Europakommisjonen (2016). European defence action plan: Towards a European defence fund. Brussel: Den europeiske union. Hentet fra http://europa.eu/rapid/press-release_IP-16-4088_en.htm

Europakommisjonen (2018). EU budget: Commission proposes increased funding to invest in connecting Europeans with high-performance infrastructure. Hentet fra http://europa.eu/rapid/press-release_IP-18-4029_en.htm

Europaparlamentet (2018). European defence industrial development programme (EDIDP). Brussel: Europaparlamentet. Hentet fra http://www.europarl.europa.eu/RegData/etudes/BRIE/2018/623534/EPRS_BRI (2018)623534_EN.pdf

EU (2009a). Directive 2009/81/EC of the European Parliament and of the Council, on the coordination of procedures for the award of certain works contracts, supply contracts and service contracts by contracting authorities or entities in the fields of defence and security, and amending directives 2004/17/EC and 2004/18/EC. Hentet fra https:/eur-lex.europa.eu/LexUriServ/LexUriServ.do?uri=OJ: L:2009:216:0076:0136:en:PDF

EU (2009b). Directive 2009/43/EC of the European Parliament and of the Council of 6 May 2009 simplifying terms and conditions of transfers of defence-related products within the Community. Hentet fra https:// eur-lex.europa.eu/LexUriServ/LexUriServ.do?uri=OJ:L:2009:146:0001:0036:en:PDF

EU (2016). Shared vision, common action: A stronger Europe. A global strategy for the European Union's foreign and security policy. Brussel: EEAS. 


\section{Kari Tvetbråten og Bjørn Olav Knutsen}

EU (2017). Notification on permanent structured cooperation (PESCO) to the Council and to the High Representative of the Union for Foreign Affairs and Security Policy.

EU (2018a). Permanent structured cooperation - PESCO. Deepening defence cooperation among EU member states. Hentet fra https://cdn2-eeas.fpfis.tech.ec.europa.eu/cdn/farfuture/fh8qF6EpUC0jEROGuHVnd AkwllNnkpPBJNawr7S2agM/mtime:1529922032/sites/eeas/files/pesco_factsheet_22-06-2018_2.pdf

EU (2018b). Defence cooperation: Council launches 17 new PESCO projects. Hentet fra https://www.consilium. europa.eu/en/press/press-releases/2018/11/19/defence-cooperation-council-launches-17-new-pescoprojects/

EUISS (2016). Report of the group of personalities on the preparatory action for CSDP-related research. Brussels/ Paris: EUISS. Hentet fra https:/www.iss.europa.eu/content/report-group-personalities-preparatory-actioncsdp-related-research

Fevolden, A. M. \& Tvetbråten, K. (2016). Defence industrial policy - a sound security strategy or an economic fallacy? Defense Studies, 16(2), 176-192. Hentet fra https://www.tandfonline.com/doi/full/10.1080/14702 436.2016.1169893

Fiott, D. (2015). The European Commission and the European Defence Agency: A case of rivalry? fournal of Common Market Studies, 53(3), 542-557.

Fiott, D. (2018). EU defence capability development. Plans. Priorities, projects. Brief Issue. Brussel: EUISS.

Frisvold, P. J. (2014). Mot Europa. Fortellingen om et nølende Norge. Oslo: Origami.

Græger, N. (2002). Norway and the EU security dimension: A «troops-for-influence» strategy. I N. Græger, H. Larsen \& H. Ojanen (Red.), The ESDP and the Nordic countries: Four variations on a theme (s. 33-89). Helsinki: Finnish Institute for International Affairs / Berlin: Institut für Europäische Politik (IEP).

Græger, N. (2005). Norway between NATO, the EU and the US: A case study of post-Cold War security and defence discourse. Cambridge Review of International Affairs, 18(1), 89-108.

Hallams, E. \& Schreer, B. (2012). Towards a "post-American» alliance? NATO burden-sharing after Libya. International Affairs, 88(2), 313-327. Hentet fra https://academic.oup.com/ia/article-abstract/88/2/313/2 326506? redirectedFrom $=$ PDF

Howorth, J. (2019). Autonomy and strategy: What should Europe want? Security policy brief 110. Brussel: Egmont Institute. Hentet fra http:/www.egmontinstitute.be/content/uploads/2019/04/SPB1 10.pdf?type=pdf

IISS (2017). The military balance 2017. Hentet fra https://www.tandfonline.com/toc/tmib20/117/1 ?nav=tocList

Juncker, J. C. (2016). State of the union speech, 14. september 2016. Hentet fra https://ec.europa.eu/ commission/priorities/state-union-speeches/state-union-2016_en

Juncker, J. C. (2017). State of the union speech, 13. september 2017. Hentet fra https://ec.europa.eu/ commission/priorities/state-union-speeches/state-union-2017_en

Knutsen, B. O. (2000). The Nordic dimension in the evolving European security structure and the role of Norway. Occasional papers 22. Paris: Western European Union (WEU). Hentet fra https://www.iss.europa.eu/ content/nordic-dimension-evolving-european-security-structure-and-role-norway

Knutsen, B. O. (2017). Utviklingen av droner og EUs søken etter strategisk autonomi. FFI-rapport-17/01208. Kjeller: Forsvarets forskningsinstitutt.

March, J. G. (1991). How decisions happen in organizations. Human-computer interactions volume 6 (s. $95-$ 117). Stanford, CA: Lawrence Erlbaum Associates, Inc.

March, J. G. (1994). A primer on decision-making. How decisions happen. New York: Free Press.

March, J. G. \& Olsen, J. P. (1989). Rediscovering institutions. The organizational basis of politics. New York: Free Press.

March, J. G. \& Olsen, J. P (1996). Institutional perspectives on political institutions. Governance.An International Fournal of Policy and Administration, 9(3), 247-264.

Melby, S. (2017). USAs ledervilje svikter. Maktpolitiske utfordringer og nye nasjonale forutsetninger. Oslo: Fagbokforlaget.

Meld. St. nr. 9 (2015-2016). Nasjonal forsvarsindustriell strategi. Oslo: Forsvarsdepartementet.

Meld. St. nr. 19 (2017-2018). Eksport av forsvarsmateriell fra Norge i 2017, eksportkontroll og internasjonalt ikkespredningssamarbeid. Oslo: Utenriksdepartementet.

Menon, A. (2013). Defence policy and the logic of «high politics». I P. Genschel \& M. Jachtenfuchs (Red.), Beyond the regulatory policy? The European integration of core state powers (s. 67-85). Oxford: Oxford University Press.

Moravcsik, A. (1998). The choice for Europe: Social purpose and state power from Messina to Maastricht. Ithaca, NY: Cornell University Press.

Munich Security Report (2017). Post-truth, post-west, post-order? Hentet fra https://www.securityconference.de/ en/publications/munich-security-report/munich-security-report-2017/ 
Olsen, E. D., Rosén, G. \& Trondal, J. (2017). Hvordan virker EU? Institusjoner og politiske prosesser. Oslo: Universitetsforlaget.

Olsen, J. P. (2002). The many faces of Europeanization. FCMS: fournal of Common Market Studies, 40(5), 921-952.

Regjeringen (2017). Norge og Tyskland inngår omfattende samarbeid om forsvarsmateriell. Hentet fra https:/www.regjeringen.no/no/aktuelt/norge-og-tyskland-inngar-omfattende-samarbeid-om-maritimtforsvarsmateriell/id2568087/

Riddervold, M. (2016). (Not) in the hands of the member states: How the European commission influences EU security and defence policies. Fournal of Common Market Studies, 54(2), 353-369.

Rieker, P. (2006). Europeanisation of national security identity. The EU and the changing security identities of the Nordic states. London, UK: Routledge.

Simon, H. A. \& March, J. G. (1993). Introduction to the Second Edition, i Organization (s. 1-19). Cambridge, MA: Blackwell.

SIPRI (2017). SIPRI Yearbook 2017. Armaments, disarmament and international security. Stockholm: SIPRI. Hentet fra https://www.sipri.org/yearbook/2017

Scott, W. R. \& Davis, G. F. (2016). Organizations and organizing. Rational, natural, and open systems perspectives. International student edition. New York: Routledge.

Sjursen, H. (2014). Demokrati eller handlingskapasitet? Paradokser i Norges tilknytning til EU på det utenriksog sikkerhetspolitiske området. I E. O. Eriksen \& J. E. Fossum (Red.), Det norske paradoks. Om Norges forhold til Den europeiske union (s. 174-195). Oslo: Universitetsforlaget.

Sjursen, H. (2016). Integrasjon uten føderasjon: EUs utenriks- og sikkerhetspolitikk. Norsk Statsvitenskaplig Tidsskrift, 41(4), 320-341.

Sluttkommunike mellom Frankrike og Tyskland (2017). Hentet fra https://www.diplomatie.gouv.fr/en/countryfiles/germany/events/article/europe-franco-german-declaration-19-06-18

Strikwerda, J. (2017). Sovereignty at stake? The European Commission's proposal for a defence and security procurement directive. European Security, 26(1), 19-36.

Strikwerda, J. (2018). Unexpected compliance? The implementation of the defence and security procurement directive. Fournal of European Integration. Hentet fra https://www.tandfonline.com/doi/abs/ 10.1080/07036337.2018.1482288?tokenDomain=eprints\&tokenAccess=cSksx4jgR2uzbfKGJ4VY\& forwardService $=$ show FullText $\&$ doi $=10.1080 \% 2 \mathrm{~F} 07036337.2018 .1482288 \&$ doi $=10.1080 \%$ 2F07036337.2018.1482288\&journalCode=geui20

Strikwerda, J. (2019). Integration in the European Union's field of defence and security. Oslo: Faculty of Social Sciences.

Valasek, T. (2011). Surviving austerity: The case for a new approach to EU military collaboration. London, UK: Centre for European Reform. Hentet fra https://www.cer.eu/publications/archive/report/2011/survivingausterity-case-new-approach-eu-military-collaboration

\section{Abstract in English \\ What Now, Norwegian Defence Industry? Instrumental and Institutional Answers to the EU's New Security and Defence Policies}

The article discusses the EU's new defence package with emphasis on CARD (Coordinated Annual Review on Defence), PESCO (Permanent Structured Cooperation) and EDF (European Defence Fund). The aim is to strengthen the EU as a security actor and encourage strategic autonomy. This package challenges Norwegian security, defence, and defence-industrial policies. The research questions are: What consequences will these EU initiatives have for Norwegian defence-industry and defence-research policies? How will the authorities (Ministry of Defence; MoD) act to maintain a national defence industry? We apply instrumental and institutional theories. Instrumental theories expect rational actions in accordance with logic of consequences. Institutional theories expect appropriate actions in line with established 
culture and expectations in their surroundings. The EU's security and defence policy becomes more similar to other EU policy areas. Therefore, a multilevel governance approach is relevant. Our interviews with representatives of Norwegian authorities and Norway's defence industry reveal that they have fragmented knowledge and expectations about the significance of the defence package. We conclude that the authorities act instrumentally, but the lack of a comprehensive understanding makes it difficult to answer rationally. The authorities therefore also act according to a cultural perspective.

Keywords: EU • organization theory $\cdot$ defence research policy $\cdot$ defence industrial policy 


\section{Appendiks A}

Intervju 1: ansatt i forsvarsindustrien, 9. oktober 2018

Intervju 2: ansatt i forsvarsindustrien, 11. oktober 2018

Intervju 3: ansatte i forsvarsindustrien, 15. oktober 2018

Intervju 4: myndighetspersoner, 16. oktober 2018

Intervju 5: ansatt i forsvarsindustrien, 17. oktober 2018

Intervju 6: ansatt i forsvarsindustrien, 18. oktober 2018

Intervju 7: myndighetsperson, 29. oktober 2018

Intervju 8: myndighetsperson, 31. oktober 2018

Intervju 9: myndighetsperson, 15. november 2018

Intervju 10: myndighetsperson, 16. november 2018 